\title{
DEFICIENCY OF MATERIAL DESCRIPTION IN ISLAMIC MANUSCRIPTS OF THESAURUS OF INDONESIAN ISLAMIC MANUSCRIPTS (TIIM)
}

\author{
Alfida \\ Department of Library Information Science \\ Syarif Hidayatullah State Islamic University Jakarta, \\ Indonesia \\ alfida@uinjkt.ac.id
}

\begin{abstract}
The increasing of digital surrogates programs for Islamic manuscripts in recent years gives positive things in protecting manuscripts value as both cultural heritage and an academic source. Thesaurus of Indonesian Islamic Manuscripts has long been done the program. The creation of this finding aid allows individuals to browse a surrogate to get the knowledge of the content and the physical and artistic features of Islamic manuscripts collection. However, those records seem remained largely inaccessible to the public since material description, including codicological and palaeographical aspects sometimes are not necessarily representing the manuscript. Through analyzing the catalogs and following the AMREMM standard and HathiTrust cataloging description with modifications regarding palaeographic and codicological features of the manuscripts, the study attempts to analyze to what extent this digital surrogates program has been covered southeast Asian Islamic manuscripts. It also highlights how the standard applied in two programs. The study shows that there are many aspects of this database that should be covered to increase manuscript research.
\end{abstract}

Keywords--Islamic manuscripts; digital Islamic manuscripts; manuscripts cataloging standards; research; AMREMM.

\section{INTRODUCTION}

Islamic manuscripts are our most important sources for more than a millennium of history and culture. The existence of the manuscripts as an identity and Indonesia's cultural heritage offers us a wealth of information on about Indonesia civilization. Most of manuscripts Indonesia is about Islam because manuscripts tradition come along with the coming of Islam to Indonesia. Recently, there are many digitization projects to preserve and increase access of the manuscripts as valuable and vulnerable artifacts so that make them available online. Among online manuscripts collections websites have been built by many institutions, including Center for Research and Development of Religious Literature and Heritage, Ministry of Religious Affairs Indonesia (Puslitbang Lektur dan Khazanah Keagamaan).

Increased access to the manuscripts collection is expected to contribute to the many research in Indonesia, especially by academics or students. In other words, the manuscripts collection websites are designed to provide detailed information to make higher quality research. Regardless of the availability of digital manuscripts, Fathurahman [1] considered that there is still a bit of research in Indonesia that make use of manuscripts collections available. Similarly, Elmawa [2] mentions that although philology has been thought for many years at Public Islamic Higher Education in Indonesia, only a few number of research on manuscripts. Iswanto [3] also found that only a few number of research on manuscripts when he analyses manuscripts studies which done by the bachelor, graduate and doctoral degree (Ph.D. thesis) students in Indonesia.

In contrast, the number of manuscripts studies actually have a dramatic increase in many areas. Kyto and Peikola [4] mention that recently, there is a significant increase in manuscript studies than ever before. This development reflects both new theoretical directions and methodological innovations uses in the studies. The increased of manuscript studies manifests a paradigm shift that highlights the importance of the material context of manuscripts. Philologists are now increasingly seen to include non-textual features of the physical manuscripts (artifact) as contextual variables in their analyses. In doing so, they are informed by research in codicology and paleography to scrutinize the physical structure, handwriting, layout, decoration, and provenance of manuscripts. The interest in manuscript studies is also closely associated with the emergence of digital humanities and the increasing collaboration between philologists and specializes in digital media and computing science to develop new research tools and methods [5]. Recent decades have seen remarkable trends in the advancement of Islamic manuscript studies which contextualized within the larger projects of manuscript cultural history, intellectual history, social history, art history, and philology for the various locales, cultures, and literary outputs since the dissemination of digital manuscripts are influencing scholarship. Richards and Schurink [7] reveal that the change of manuscripts study from only textual to material aspect is 
reflected in the increasing number of books and articles analyzing marginal annotations to early modern literary and other types of texts and exploring their significance for our understanding of the reception of these books. So that, it is an opportune time to extend the models of manuscripts use and to renew attention from the textuality aspect to material aspect in terms of visuality of manuscripts. Thus, the literary study also turns its attention to manuscripts marginalia responses to texts and paratexts to reflect on the reception of literary or reader response at the certain time. To fulfill this studies, the existence of manuscripts is a must. Another source that students can use is the description of manuscript in the form of catalog description of manuscripts.

However, manuscript catalogs description has aroused some problems notably, the description of manuscripts which reflect in deficiency or lack of metadata as a surrogate of the original item. Lack of metadata standardization may hinder people to explore the performance of manuscripts, including information about the material description of manuscripts. Whether material features including information on dating and other aspects of the essential physical context in which any study of manuscript content should be provided. Deficits in material aspect raise concerns that dissemination of digital surrogates for Islamic manuscripts is enabling the neglect of material qualities.

Responding to the number of Islamic manuscripts researches done in Indonesia is still lacking, coupled with the studies are more focus on textuality (not materiality), it is important to analyze on how Islamic manuscripts information can be found. TIIM is one of the places that researchers can go to see Islamic manuscript descriptions. For that reasons, the aim of this research is to investigate cataloging description of TIIM regarding materiality information that enables to increase research on Islamic manuscripts. The specific objectives to achieve this main goal are identified as follows: Firstly, this research will identify on how the description of TIIM metadata produce material aspect of Islamic manuscripts; Secondly, this research will assess how this database is suited with AMREMM cataloging rule; Thirdly, this research will compare TIIM with HathiTrust catalog (a catalog which offers a collection of millions of titles digitized from libraries around the world, including manuscripts) regarding cataloging description.

\section{THEORETICAL BACKGROUND}

Islamic manuscripts material description, as it is mentioned in a metadata catalog offers multiple tools to help learners locate information. Due to these benefits, several studies attempt to discuss the increase of research and metadata improvement. In analyzing physical realization (material, layout, writing, corrections, music, illustrations, and additions) of Bodleian Medingen Psalter manuscripts, Henrike [8] explains that the new significance manuscripts acquired as the art of printing developed that emphasized the material side of their text production. Echard [9] mentions that the digital age has expanded the area of manuscripts materializations which are important in the understanding of the Middle Ages objects. She states that scholarly attitudes toward the Middle Ages are, part of the web of popular perception and reception, a web in which the physical object and the imaginative response are inextricably linked. In her studies of the Rāmamālā Library in Bangladesh and the Indic collection at the University of Pennsylvania, Fleming [10] acknowledges that South Asian manuscript traditions can contribute to the understanding of the materiality of texts. Considering on how different articulations of orality, memory, ritual, and aesthetics in Hinduism, Buddhism, and Jainism will help to shape the development and formation of manuscript traditions in South Asia. Hubbard [11] illustrates how the page of the codex went from being a plain sheet of parchment with a block of handwritten text to a dynamic matrix of ornamentation, illustration, and punctuation. He discusses how these textual elements function similarly the same way as information architecture and wayfinding techniques used in hypertexts today. Due to the importance of material described in the form of metadata, several studies demonstrate the model of metadata, which is a structured dataset that describes any resource. The proposed model of metadata content standard on the studies including Resource Description and Access (RDA), Descriptive Cataloguing of Ancient, Medieval, Renaissance and Early Modern Manuscripts (AMREMM), Dublin Core Metadata Initiatives Vocabularies (DCMI), etc.

\section{METHODS}

To achieve the aim of this research, the research tries to analyze TIIM website. It is then compared with a prominent standard regarding manuscript cataloging description. AMREMM standard description from Descriptive cataloging of ancient, medieval, Renaissance, and early modern manuscripts by Pass [12] has been chosen as a guideline which was developed as part of a project entitled Electronic Access to Medieval Manuscripts (EAMMS), funded by the Andrew W. Mellon Foundation. These guidelines received further criticism and development within the Bibliographic Standards Committee of the Rare Books and Manuscripts Section of the Association of College and Research Libraries, a division of the American Library Association; in addition to which they were reviewed by a special task force of the Committee on Cataloging: Description and Access of the Association for Library Collections \& Technical Services, a division of the American Library Association. They were then finally approved by the Executive Committee of the Rare Books and Manuscripts Section of the Association of College and Research Libraries. It then analyzes cataloging description in HathiTrust digital library https://catalog.hathitrust.org/ for its catalog description. Research results based on the application of both standard. 


\section{DISCUSSION AND RESULTS}

Cataloging description intend outcome was a searchable database of transcriptions, notes, and headings that would represent not only the contents of the codices - text, paratext, image, and ornament-but also their material form via further notes addressing the script and hand, structure (i.e.composition of gatherings, sewing, cover, and attachment), dimensions, writing material, layout, and other material aspects. the creation and deployment of digital surrogates that contributors could examine to ascertain and provide the requested descriptive details for the manuscripts as comments on existing preliminary descriptions posted to a project site. Features such as visual content, decoration, layout, writing material, and binding were almost completely neglected, although aspects of those features were ascertainable via the surrogates provided. Metadata are means to the content for users when accessing content, which is used mainly as intermediate steps to retrieve content in a digital library. Metadata is the connection player between content and technologies in digital libraries. Metadata have been invented to form a basis for navigation in data sets of large scale. The qualities of cataloging description determine the scholarly uses it can afford. One disadvantage to relying upon existing nonspecialized standards is that they may not be able to account for all the pertinent metadata that should be included in an archival record [13].

\section{Material Aspect of TIIM Manuscripts Description}

Thesaurus of Indonesia Islamic Manuscripts is a database designed by the Islamic Manuscript Unit on the Center for the Study of Islam and Society (PPIM), Syarif Hidayatullah State Islamic University (UIN) and fully supported by the Center for Research and Development of Religious Literature (Center for Religious literature), Ministry of Religious Affairs of Indonesia. The Thesaurus of Indonesian Islamic Manuscripts is mainly intended to provide information as complete as possible on Indonesian Islamic manuscripts, which are written both in Arabic and local languages, including Acehnese, Buginese, Javanese, Madurese, Malay, Minangkabau. TIIM is the important source for philologists, historians, and scholars of Southeast Asian Islamic Studies who are keen to see the characteristics of local Islam in the past. The written treasury is strong evidence that Indonesia can be considered a world center for Islamic studies. It is the potential database that contains manuscripts information mainly found in Indonesia, even in the database we found that it will develop as the southeast Asia manuscripts information.

In describing the manuscripts, TIIM covers manuscript Subject Matter Language Script the owner of the collection, Catalogue, and Research. For example manuscripts with the title "Futūhāât al-Ilāhīyah bi-tawḍīh tafsīr al-jalālayn. It mentions that the author is Sulaymān bin 'Umar al-'Ujaylī al-Azharī al-shahīr bi al-Jamāl. The place of his birth in Egypt, and he died in 1790 M. the language and script that the manuscript uses were Arabic. The subject matter was Quranic Exegesis. The genre was prose, and date of Autograph was 18th. Under that description, there are notes of the manuscripts. The notes contain information that this written treasury was written in $1196 \mathrm{H}$. The following notes mention that this is a commentary (sharh) to Tafsīr al-Jalālayn of al-Maḥallī and al-Suyūṭī. In this work, alJamāl describes what is found in the Jalālayn then explains the opinions of both al-Mahallī and al-Suyūṭ̂, etc. It is true that the description of this manuscript is rich in information about what the manuscripts about. So that, people seem to understand the content of the manuscript. However, it is more on an analytical bibliography, not a descriptive bibliography. So, TIIM opens a little window for researchers to study on the text, not on its materials.

\section{Following AMREMM Cataloging Rule standard}

Regarding AMREMM standard, there are several things that need to be analyzed in order to produce the material description in the form of metadata, including title and statement of responsibility. This area covers any alternative title, parallel title, other title information, statements of responsibility, or statements of edition/version. Following this standard, it is true that we cannot follow the element in describing the manuscripts because many Islamic manuscripts in Indonesia have no colophon. The second thing is place and date of manuscripts production area. This information can be found in colophon or another explicit statement of place or date of production. The other area to find this information derive from any available localizable or datable textual or physical evidence including content, script, decoration, etc. Also, it can be seen from the alternative source of information, such as a reference work, published article, or scholarly communication, etc. The third thing that needs to be analyzed is the place of manuscripts production. The information also can be found in the date can be established for an item, or known date or range of dates based upon localizable or content, script, decoration, etc. The above things mentions will be important to be the focus of manuscripts research. The increasing researchers on the dating of the manuscripts have proven that there is a certain and special time for author or copyist to write their manuscripts.

The fourth thing is a physical description. This area is important to mention about a material description of the manuscripts. There are two things which cover physical description. They are illustrative matter and dimension. In doing manuscripts catalog, it needs to describe any illustrations, illuminations, calendars, canon tables, genealogical tables, diagrams, or maps, which present in the manuscripts. The catalog also important to provide dimensions for the written space and layout of the page. Dimension can be found in frame ruling and written above the top line of manuscripts. Dimension is also about dimensions of the gloss or commentary, and dimensions of any illustration, illumination, or other decoration situated within the text. Analyzing information on physical 
description, there will be many ideas to be topics on manuscripts studies.

The last thing but not the least to get the material description of the manuscripts is a note area. AMREMM clarifies that in this area, there are many things that material description will cover including layout, script, decoration, illumination, binding, and accompanying materials. The information does not overlap with the physical description area since it only covers what physical description not. However, many manuscript catalogs whether they are printed or online version always fill note area with the content of the manuscripts. In order to describe a kind of complete material description of manuscripts, HathiTrust digital library which includes manuscripts catalog website is a good place to visit and see how this digital library provide the material description of the manuscripts in their metadata.

\section{HathiTrust and TIIM Material Descriptions}

To provide information on the material description of these two sources, there will be samples of entry on Koran (Qur'an) chosen. The chosen manuscript from HathiTrust is Koran: manuscript, [1550-161-?]. It is stated the other author, language, and subject and sub-subject. For example, Manuscripts, Arabic > Michigan > Ann Arbor. HathiTrust only gives information on title, author, language, and subject of this manuscript. Yet, what HathiTrust has done have they put in note area such as, the number of illumination in a certain page in the manuscripts. Then, there is information on chapter heading which was written in gold as gold and polychrome roundels mark the end of each verse 30 subsections indicated in margins in a gold script; the color of text enclosed in borders, the pattern of edges gilded. Besides, it enclosed information on dating, date of the original copy, copyist's name, and provenance. There is also information on manuscripts purchasing, place and date, and the owner of another part of manuscripts. The description above signifies the manuscripts in every aspect including material aspect description. Each of information mentioned about the manuscripts will be an important source of scholarship.

By the same token, TIIM mentions the same subject of its manuscript kind, which is Mushaf Kuno al-Qur'an Pandeglang. TIIM yields the title, language, script, subject matter, and genre. TIIM also provides us with information on bibliography, catalog, and research that has been done using the manuscript mentioned. This also provides some other useful information such as a name of the author with their biographical accounts, catalogs that list the related manuscripts including their pages and summaries, and all related articles and books. However, this source doesn't give any material description whether it is in physical description area or in a note area. In fact, the ability to recognize the significance of the physical features of manuscripts will give opportunities for scholars working with the digital manuscripts. Islamic may be more inclined to neglect the significance of physical qualities and even the essential historical context of the manuscript content they are studying. That is to say, that performing descriptive tasks working with both physical manuscripts and digital surrogates can impart a better understanding of manuscript features and appreciation for physical aspects.

To make the appropriate material description, cataloger who creates metadata will be much important. This is what this research limitation mentioned. There is no triangulation of data that can be obtained from cataloging or metadata team. The team is very important to ask because it could have some reasons why it made the description as such. Furthermore, the aspect that has not been much discussed is related to the needs of the information required by the researcher. In other words, this study included respondents from students who had attended the course philology. If this research is also directed to researchers interested in Islamic manuscript, of course, the results obtained will be different.

\section{CONCLUSION}

The findings show that generally, description of TIIM metadata produces material aspect of Islamic manuscripts. However, there should be much more information regarding materiality paleography and codicology aspects. Regarding AMREMM cataloging rule, there are several important points that need to be considered including, subject analysis, detail description, arrangement and any materiality aspect which mention in a note area. In terms of physical description that has been mentioned in HathiTrust digital library, TIIM needs to cater. In general, the proposed application profile includes appropriate and necessary fields, but some refinements may still be desirable. This straightforward manuscripts standard will fill a need among small institutions and for individual researchers who are creating metadata for manuscripts. By combining medieval manuscripts with those needed for digital dissemination and discovery on the Web in an easy-to-learn and easy-to-use metadata application profile, the more material aspect of manuscripts may be discovered, analyzed, and incorporated into many studies. TIIM thesaurus of Indonesian Islamic manuscripts should consider redesigning the presentation of the website's interface, including the completion of the download menu, menu search and browsing improvements. TIIM requires extensive metadata to improve data collection and analysis. The heterogeneity of the collected metadata grows as research is evolving into international multidisciplinary collaborations and increasing data sharing among institutions.

References

[1] O. Fathurahman, "Thesaurus of Indonesian Islamic Manuscripts (T2IM): An Effort to Develop a Comprehensive Database for Academic Purpose," Stud. Islam., vol. 16, no. 3, 2009. 
[2] M. Elmawa, "Filologi Nusantara dan Perpustakaan: Potret Layanan Khusus Pengguna Studi Islam Indonesia," Pustakaloka, vol. 8, p. 57, Jul. 2016.

[3] A. Iswanto, "Kecenderungan Kajian Manuskrip Keislaman Di Uin Syarif Hidayatullah Jakarta," Al-Qalam, vol. 21, no. 1, pp. 107-116, Jan. 2016.

[4] M. Kytö and M. Peikola, "Philology on the Move: Manuscript Studies at the Dawn of the 21st Century," Studia. Neophilologica., vol. 86, no. sup1, pp. 1-8, May 2014.

[5] Evyn C. Kropf, "Will that Surrogate Do?: Reflections on Material Manuscript Literacy in the Digital Environment from Islamic Manuscripts at the University of Michigan Library," Manuscr. Stud., vol. 1, no. 1, p. 1, 2017.

[6] N. Audenaert and R. Furuta, "What Humanists Want: How Scholars Use Source Materials," in Proceedings of the 10th Annual Joint Conference on Digital Libraries, New York, NY, USA, 2010, pp. 283-292.

[7] J. Richards and F. Schurink, "Introduction: The Textuality and Materiality of Reading in Early Modern England," Huntingt. Libr. Q., vol. 73, no. 3, pp. 345-361, Sep. 2010.

[8] Henrike L, "The Materiality of South Asian Manuscripts from the University of Pennsylvania MS Coll. 390 and the Rāmamālā Library in Bangladesh,” Oxf. Ger. Stud., 2016.

[9] S. Echard, Printing the Middle Ages. Philadelphia: PENN/University of Pennsylvania Press, 2008.

[10] B. Fleming, "The Materiality of South Asian Manuscripts from the University of Pennsylvania MS Coll. 390 and the Rāmamālā Library in Bangladesh," Manuscripts. Studies., vol. 1, no. 1, Jun. 2017.

[11] Melanie Hubbard, "Materializing Hypertexts: Bridging the ' Gap' Between Digital and Analog," Digital. Initiative. Symposium. 17, 2015.

[12] Gregory A. Pass, Descriptive Cataloging of Ancient, Medieval, Renaissance, and Early Modern Manuscripts. American Library Association, 2004.

[13] M. O. Soualah and M. Hassoun, "Which metadata for Ancient Arabic Manuscripts Cataloguing?," Int. Conference. Dublin Core Metadata Appl., vol. 0, pp. 137146, Sep. 2011. 